\title{
Resveratrol synergizes with cisplatin in antineoplastic effects against AGS gastric cancer cells by inducing endoplasmic reticulum stress-mediated apoptosis and $\mathrm{G} 2 / \mathrm{M}$ phase arrest
}

\author{
MENGTING REN ${ }^{*}$, XINXIN ZHOU* , MENGLI GU, WENRUI JIAO, MOSANG YU, \\ YAMEI WANG, SHA LIU, JINPU YANG and FENG JI \\ Department of Gastroenterology, The First Affiliated Hospital, College of Medicine, \\ Zhejiang University, Hangzhou, Zhejiang 310003, P.R. China
}

Received December 2, 2019; Accepted July 1, 2020

DOI: 10.3892/or.2020.7708

\begin{abstract}
Gastric cancer (GC) is a common gastrointestinal malignancy, and cisplatin (DDP) is an important component of chemotherapeutic regimens for GC. However, the application of DDP is limited by its dose-dependent systemic toxicity. Resveratrol (RES) is a natural polyphenol compound that has chemopreventive and therapeutic effects against various cancers, including GC. However, whether RES can sensitize GC cells to DDP remains unknown. Following RES/DDP combination treatment, cell viability was determined by Cell Counting Kit- 8 and colony-forming assays, and cell apoptosis and the cell cycle were detected by FITC-Annexin V/PI staining assay and PI staining assay, respectively, followed by flow cytometry. Moreover, western blotting was performed to evaluate the protein expression levels, and the intracellular free $\mathrm{Ca}^{2+}$ concentration was determined by a Fluo-4 AM probe after cell cotreatment with RES and DDP. The present results demonstrated that RES/DDP combination treatment significantly inhibited cell viability, promoted cell apoptosis and induced G2/M phase arrest in AGS cells. In addition, it was determined that RES combined with DDP significantly increased the levels of Bax, cleaved poly-ADP-ribose polymerase (PARP), glucose-regulated protein 78 (GRP78), PRKR-like ER kinase (PERK), p-eukaryotic translation initiation factor $2 \alpha$ (p-eIF2 $\alpha$ ), CCAAT/enhancer binding protein homologous protein (CHOP) and cleaved caspase-12, whereas Bcl-2 expression was downregulated following RES/DDP cotreatment. Moreover, RES/DDP cotreatment
\end{abstract}

Correspondence to: Dr Feng Ji, Department of Gastroenterology, The First Affiliated Hospital, College of Medicine, Zhejiang University, 79 Qingchun Road, Hangzhou, Zhejiang 310003, P.R. China

E-mail: jifeng@zju.edu.cn

*Contributed equally

Key words: resveratrol, gastric cancer, cisplatin, apoptosis, endoplasmic reticulum stress, G2/M cell cycle arrest significantly upregulated phosphorylated cyclin-dependent kinase 1 (p-CDK1, Tyr15), p21 $1^{\text {Waf1/Cipl }}$ and p $27^{\text {Kip1 }}$ protein levels and downregulated $\mathrm{Cdc} 25 \mathrm{C}$ protein levels. In conclusion, RES and DDP synergistically inhibited the growth of the gastric adenocarcinoma cell line AGS by inducing endoplasmic reticulum stress-mediated apoptosis and G2/M phase arrest via activation of the PERK/eIF2 $\alpha$ /activating transcription factor 4 (ATF4)/CHOP signaling pathway and caspase-12 and by inactivating the CDK1-cyclin B1 complex. These results indicated that RES is a promising adjuvant for DDP during GC chemotherapy.

\section{Introduction}

Gastric cancer (GC) is one of the most common gastrointestinal malignancies and remains the leading cause of cancer-related deaths worldwide, with over half of the cases occurring in East Asia $(1,2)$. Adequate surgical resection is the only curative treatment strategy for localized GC, however a high risk of recurrence and metastasis remains after surgical resection (3). Furthermore, most patients are diagnosed at an advanced stage, and chemotherapy is the first-line treatment (4). Cisplatin [cis-diamminedichloroplatinum(II); DDP] is a widely used platinum-based antineoplastic agent for GC treatment, especially for patients at an advanced stage (5). However, its application is limited by drug resistance and its systemic toxicity, such as nephrotoxicity, ototoxicity, neurotoxicity and hepatotoxicity (6). Thus, it is essential to develop novel chemical sensitizing agents for DDP to enhance its efficacy and attenuate side effects in GC patients.

Resveratrol (3,4',5-trihydroxystilbene; RES) is a nonflavonoid polyphenolic compound notably present in grapes and red wine (7). It plays a protective role against a wide variety of diseases, including cardiovascular diseases (8), neurodegenerative diseases (9), inflammatory diseases (10) and diabetes (11). Moreover, recent preclinical studies have identified RES as a chemopreventive and therapeutic agent as well as a chemical sensitizer for various malignant tumors (12), which displays lower cytotoxicity to normal cells than traditional therapy. Although previous studies have demonstrated that RES exerts its anticancer effects against GC cells by promoting apoptosis 
and inducing cell cycle arrest or suppressing migration and invasion (13-15), whether it can sensitize GC cells to DDP and the underlying mechanisms remain to be determined.

The endoplasmic reticulum (ER) is the principle organelle responsible for biogenesis, folding and trafficking of over one-third of the proteins in eukaryotic cells (16). Extrinsic and intrinsic perturbations disturb ER homeostasis, trigger ER stress and activate the unfolded protein response (UPR), which promotes cell survival, or induce apoptosis if ER stress is severe or chronic (17). In fact, the UPR promotes cancer cell survival by enhancing cancer cell adaptation to hostile environmental conditions, and regulating the UPR is a promising anticancer strategy (18). Recent studies have demonstrated that RES promoted ER stress-mediated apoptosis in colon cancer cells (19), ovarian cancer cells (20), and malignant melanoma cells (21). However, the role of RES in ER stress-induced apoptosis in GC cells has not been studied to date.

In the present study, it was revealed that RES synergized with DDP in antineoplastic effects against the human GC cell line AGS by inducing ER stress-mediated apoptosis and G2/M cell cycle arrest. Mechanistic experiments revealed that RES/DDP combination treatment activated the PRKR-like ER kinase (PERK)/eukaryotic translation initiation factor $2 \alpha(\mathrm{eIF} 2 \alpha) / \mathrm{acti}$ vating transcription factor 4 (ATF4)-CCAAT/enhancer binding protein homologous protein (CHOP) signaling pathway and upregulated cleaved caspase-12. Furthermore, RES/DDP combination treatment arrested AGS cells in G2/M phase by inactivating the cyclin-dependent kinase 1 (CDK1)-cyclin B1 complex and upregulating $\mathrm{p} 21^{\mathrm{Waf} 1 / \mathrm{Cip} 1}$ and $\mathrm{p} 27^{\mathrm{Kip}}$ protein levels. The present results provided evidence that may lead to the future application of RES as an adjuvant for GC chemotherapy.

\section{Materials and methods}

Cell culture. The human GC cell lines AGS, KATO III, MKN-45 and NCI-N87 were obtained from the Type Culture Collection of the Chinese Academy of Sciences. The AGS cells were cultured in Ham's F-12K (Kaighn's) medium (Gibco; Thermo Fisher Scientific, Inc.) supplemented with $10 \%$ fetal bovine serum (FBS), $100 \mathrm{U} / \mathrm{ml}$ penicillin and $100 \mu \mathrm{g} / \mathrm{ml}$ streptomycin (Gibco; Thermo Fisher Scientific, Inc.) at $37^{\circ} \mathrm{C}$ in a humidified incubator containing 5\% $\mathrm{CO}_{2}$. The KATO III cell line was cultured in Iscove's Modified Dulbecco's Medium (IMDM; Gibco; Thermo Fisher Scientific, Inc.), and the MKN-45 and NCI-N87 cell lines were cultured in RPMI-1640 medium (Gibco; Thermo Fisher Scientific, Inc.) as described above.

Cell Counting Kit-8 (CCK-8) assay. Cell viability was detected by a CCK-8 assay (Dojindo Molecular Technologies, Inc.). Approximately $5 \times 10^{3}$ cells/well were seeded into 96-well plates and incubated overnight at $37^{\circ} \mathrm{C}$. Next, various doses of $\operatorname{RES}(0,5,10,20,30,40,50,60,70$, and $80 \mu \mathrm{M})$ and/or DDP $(0,0.5,1$, and $2 \mu \mathrm{g} / \mathrm{ml})$ (both from Selleck Chemicals) were added. After culturing for another 24, 48, 72 or $96 \mathrm{~h}$, each well was incubated with $10 \mu \mathrm{l}$ CCK-8 solution for 1-3 h before measuring the absorbance at $450 \mathrm{~nm}$ using a microplate reader (Bio-Rad Laboratories, Inc.).

Evaluation of the combination effect of RES and DDP. The combination index (CI) was applied to evaluate the combination effect of RES and DDP in AGS cells according to the Chou-Talalay method (22). CI was calculated by CompuSyn software (ComboSyn, Inc.), and the combination effect was defined as follows: $\mathrm{CI}<1$, synergistic effect; CI $>1$, antagonistic effect; and $\mathrm{CI}=1$, additive effect.

Morphological observation. AGS cells were seeded in 6-well plates $\left(1 \times 10^{5}\right.$ cells/well), incubated at $37^{\circ} \mathrm{C}$ overnight, and exposed to RES $(20 \mu \mathrm{M})$ and DDP $(1 \mu \mathrm{g} / \mathrm{ml})$ alone or in combination for $48 \mathrm{~h}$. Cell morphology was observed using an inverted light microscope (magnification, x100; Olympus Corporation).

Colony-forming assay. AGS cells were treated with RES $(20 \mu \mathrm{M})$ and DDP $(1 \mu \mathrm{g} / \mathrm{ml})$ alone or in combination for $48 \mathrm{~h}$. Thereafter, the cells were trypsinized by $0.25 \%$ trypsin (Gibco; Thermo Fisher Scientific, Inc.) and dispensed into individual wells of 6 -well plates at a density of $1 \times 10^{3}$ cells/well. Following another 14 days of drug-free culture and changing of the medium every other day, the cells were fixed with $4 \%$ paraformaldehyde at $25^{\circ} \mathrm{C}$ for $15 \mathrm{~min}$ and stained with $0.1 \%$ crystal violet at $25^{\circ} \mathrm{C}$ for another $15 \mathrm{~min}$. Finally, colonies ( $\geq 10$ cells) were counted using an inverted light microscope (magnification, x100; Olympus Corporation).

Cell apoptosis assay. Apoptotic cells were detected by an FITC-Annexin V Apoptosis Detection Kit (BD Biosciences) according to the manufacturer's instructions. The cells $\left(1 \times 10^{5} /\right.$ well $)$ were seeded in 6-well plates and incubated overnight at $37^{\circ} \mathrm{C}$. Then, the cells were treated with RES $(0,20$, and $40 \mu \mathrm{M})$ for $72 \mathrm{~h}$ or exposed to $\operatorname{RES}(20 \mu \mathrm{M})$ and DDP $(1 \mu \mathrm{g} / \mathrm{ml})$ alone or in combination for 48 and $72 \mathrm{~h}$. Subsequently, the cells were harvested with EDTA-free trypsin and resuspended in $500 \mu \mathrm{l}$ of $1 \mathrm{X}$ binding buffer followed by incubation with FITC-Annexin V $(5 \mu \mathrm{l})$ and PI $(5 \mu \mathrm{l})$ at $25^{\circ} \mathrm{C}$ in the dark for $15 \mathrm{~min}$. Finally, the apoptotic cells were analyzed by a BD FACSCanto II flow cytometer (BD Biosciences) and FlowJo software (version 10.4; BD Biosciences).

Cell cycle assay. The cell cycle assays were performed according to the manufacturer's instructions using a cell cycle staining kit [MultiSciences (Lianke) Biotech Co., Ltd.] as previously described (23). After administration of RES $(20 \mu \mathrm{M})$ and DDP $(1 \mu \mathrm{g} / \mathrm{ml})$ alone or in combination, the cells were harvested and fixed with $75 \%$ ethanol at $-20^{\circ} \mathrm{C}$ overnight. Thereafter, the cells were hydrated with cold phosphate-buffered saline (PBS) for $15 \mathrm{~min}$ and incubated with DNA staining solution at $25^{\circ} \mathrm{C}$ for $30 \mathrm{~min}$ in the dark before evaluation by a BD FACSCanto II flow cytometer and ModFit LT software (version 5.0.9; Verity Software House Co., Ltd.).

Detection of intracellular free calcium ions $\left(\mathrm{Ca}^{2+}\right)$. The intracellular free $\mathrm{Ca}^{2+}$ concentration was determined by the calcium probe Fluo-4 AM (Beyotime Institute of Biotechnology) according to the manufacturer's instructions. After exposure to RES $(20 \mu \mathrm{M})$ and DDP $(1 \mu \mathrm{g} / \mathrm{ml})$ alone or in combination for $48 \mathrm{~h}$, the cells were collected, washed twice with PBS and incubated with $2 \mu \mathrm{M}$ Fluo-4 AM probe for $30 \mathrm{~min}$ at $37^{\circ} \mathrm{C}$. Subsequently, the cells were washed with PBS, and cell fluorescence was determined using a BD FACSCanto II flow cytometer (excitation wavelength, $488 \mathrm{~nm}$; emission wavelength, $525 \mathrm{~nm}$ ). 
Western blot analysis. Following treatment with RES (10, 20, and $40 \mu \mathrm{M})$ and DDP $(1 \mu \mathrm{g} / \mathrm{ml})$ alone or combination treatment of RES $(20 \mu \mathrm{M})$ and DDP $(1 \mu \mathrm{g} / \mathrm{ml})$ for $48 \mathrm{~h}$, total protein from AGS cells was extracted using cell lysis buffer (Cell Signaling Technology, Inc.) according to the manufacturer's instructions. Western blot analysis was performed as previously described (24). Briefly, $20 \mu \mathrm{g}$ of protein was loaded onto each lane and then transferred to polyvinylidene difluoride (PVDF) membranes. The membranes were incubated with primary antibodies overnight at $4^{\circ} \mathrm{C}$, followed by goat anti-rabbit secondary antibody (1:5,000, cat. no. HA1001; HuaBio Co., Ltd.) or goat anti-mouse secondary antibody (1:10,000, cat. no. BL001A, BioSharp Co., Ltd.) for $1 \mathrm{~h}$ at $25^{\circ} \mathrm{C}$. The primary antibodies used were rabbit antibodies against $\mathrm{CHOP}$ (also named DDIT3; 1:1,000; product code ab179823; Abcam), poly-ADP-ribose polymerase (PARP; 1:1,000; cat. no. 9532; Cell Signaling Technology, Inc.), Bax (1:1,000, cat. no. 2774; Cell Signaling Technology, Inc.), Bcl-2 (1:1,000, cat. no. 2872, Cell Signaling Technology, Inc.), glucose-regulated protein 78 (GRP78; 1:1,000; product code ab108615; Abcam), PERK (1:1,000; cat. no. 5683; Cell Signaling Technology, Inc.), eIF2 $\alpha$ (1:1,000; cat. no. 5324; Cell Signaling Technology, Inc.), p-eIF2 $\alpha$ (1:1,000; cat. no. 3398; Cell Signaling Technology, Inc.), caspase-12 (1:1,000; product code ab62484; Abcam), cyclin B1 (1:1,000; cat. no. 4138; Cell Signaling Technology, Inc.), p-CDK1 (Tyr15; 1:1,000; cat. no. 4539; Cell Signaling Technology, Inc.), Cdc25C (1:1,000; cat. no. 4688; Cell Signaling Technology, Inc.), p21 ${ }^{\text {Waf1/Cip1 }}(1: 1,000$; cat. no. 2947 ; Cell Signaling Technology, Inc.), p27 Kipl (1:1,000; cat. no. 3686; Cell Signaling Technology, Inc.) and GAPDH (1:5,000; cat. no. 2118; Cell Signaling Technology, Inc.), and mouse monoclonal antibody against CDK1 (1:1,000; cat. no. 9116; Cell Signaling Technology, Inc.). The protein bands were quantified using ImageJ software (version 1.52a; National Institutes of Health). The phosphorylated protein bands were normalized to their total protein levels, and the other bands were normalized to GAPDH.

Statistical analysis. The results are presented as the mean \pm standard deviation (SD). All statistical analyses were performed by Prism 7.0 (GraphPad Software, Inc.) using one-way ANOVA followed by Tukey's multiple comparisons test. Differences were considered to be statistically significant at $\mathrm{P}<0.05$. All experiments were performed in triplicate.

\section{Results}

RES inhibits viability and promotes apoptosis of AGS cells. First, cell viability assays in 4 GC cell lines (AGS, KATO III, MKN-45 and NCI-N87) were performed and cell apoptosis was detected in 3 GC cell lines (AGS, KATO III and MKN-45) following RES/DDP cotreatment (Figs. S1, 2B and 3A-C). It was determined that the most significant results were obtained in AGS cells. Therefore, the human gastric adenocarcinoma cell line AGS was selected for the present study. After exposure to RES, the cell viability of AGS was explored by CCK- 8 assay. The RES concentration gradient ranged from 5 to $80 \mu \mathrm{M}$. Our results demonstrated that RES displayed a dose-and time-dependent inhibitory effect on AGS cellular viability $(\mathrm{P}<0.001 ;$ Fig. 1A). Flow cytometric analysis indicated
Table I. Combination index values of RES and DDP combination treatment at $\mathrm{ED}_{50}, \mathrm{ED}_{75}$ and $\mathrm{ED}_{90}$.

\begin{tabular}{lccc}
\hline $\operatorname{RES}(\mu \mathrm{M}) / \mathrm{DDP}(\mu \mathrm{g} / \mathrm{ml})$ & $\mathrm{ED}_{50}$ & $\mathrm{ED}_{75}$ & $\mathrm{ED}_{90}$ \\
\hline $25: 1$ & 0.931 & 0.867 & 0.910 \\
$12.5: 1$ & 0.911 & 0.853 & 0.862 \\
\hline
\end{tabular}

RES, resveratrol; DDP, cisplatin; ED, effective dose.

that RES treatment $(10,20$ and $40 \mu \mathrm{M})$ consistently upregulated AGS cell apoptosis in a dose-dependent manner, with the percentage of cells undergoing apoptosis increasing from 4.06 to $41.07 \%$ with increasing RES concentration $(\mathrm{P}<0.001$; Fig. 1B and C). Furthermore, the protein expression of CHOP, an early protein in ER stress, was detected after administration of RES and DDP alone or in combination for 24,36 , and $48 \mathrm{~h}$. The most notable results were obtained for the 48-h time-point (data not shown). Thus, this time-point was selected for subsequent experiments. Western blot analysis revealed that RES administration $(10,20$ and $40 \mu \mathrm{M})$ significantly increased the protein levels of CHOP and cleaved PARP in a dose-dependent manner $(\mathrm{P}<0.05$; Fig. 1D and $\mathrm{E})$. Collectively, the present results indicated that RES exerts anticancer activity against AGS cells by inhibiting cell viability and promoting cell apoptosis.

RES and DDP synergistically inhibit AGS cell viability. To investigate the growth-inhibitory effect of RES/DDP cotreatment on AGS cells, the cells were exposed to different doses of $\operatorname{RES}(0,5,10,20$ and $40 \mu \mathrm{M})$ and DDP $(0,0.5,1$ and $2 \mu \mathrm{g} / \mathrm{ml}$ ) alone or in combination for $48 \mathrm{~h}$. The combination treatment of RES $(20 \mu \mathrm{M})$ and DDP $(1 \mu \mathrm{g} / \mathrm{ml})$ significantly suppressed viability of AGS cells compared to the viability observed under either RES treatment or DDP treatment alone (P<0.01; Fig. 2A). Therefore, $20 \mu \mathrm{M}$ and $1 \mu \mathrm{g} / \mathrm{ml}$ were selected as the concentrations for RES and DDP, respectively, for the subsequent experiments. Next, cell viability was determined following administration of RES $(20 \mu \mathrm{M})$ and DDP $(1 \mu \mathrm{g} / \mathrm{ml})$ either individually or in combination for 24, 48, 72 and $96 \mathrm{~h}$. Although exposure to RES $(20 \mu \mathrm{M})$ or DDP $(1 \mu \mathrm{g} / \mathrm{ml})$ for $24 \mathrm{~h}$ did not significantly inhibit cell viability, it was determined that RES and DDP cotreatment for 48, 72 and $96 \mathrm{~h}$ significantly inhibited AGS cell viability compared with that of either single-agent treatment $(\mathrm{P}<0.05$; Fig. 2B). As shown in Fig. 2C, RES and DDP cotreatment notably decreased the number of cells compared to the number observed under either single-agent treatment alone. Besides, cell shrinkage, detachment and reduced cytoplasm were evident in the cells under RES/DDP combination treatment (Fig. 2C). In addition, the $\mathrm{IC}_{50}$ value against AGS cells decreased from $4.779 \mu \mathrm{g} / \mathrm{ml}$ under DDP-only treatment to $3.154 \mu \mathrm{g} / \mathrm{ml}$ under combination DDP/RES $(20 \mu \mathrm{M})$ treatment (data not shown). Furthermore, the analysis of $\mathrm{CI}$ values by CompuSyn software at $\mathrm{ED}_{50}$, $\mathrm{ED}_{75}$ and $\mathrm{ED}_{90}$ (Table I) indicated that RES and DDP have synergistic inhibitory effects on AGS cell viability (22). The results of colony-forming assays indicated that the combination treatment significantly suppressed AGS cell viability over that attained by RES or DDP treatment alone $(\mathrm{P}<0.001$; 

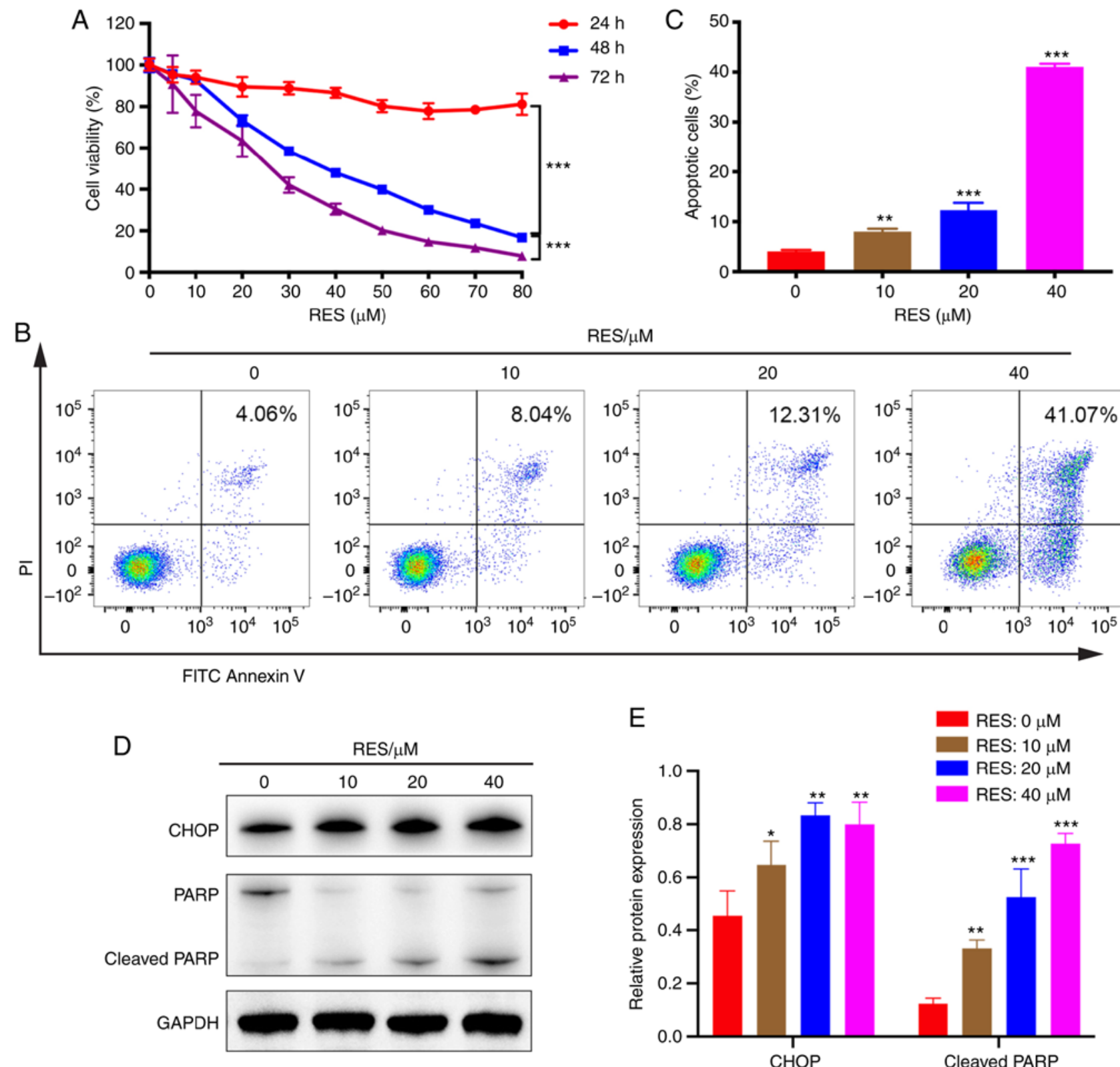

$\mathrm{RES} / \mu \mathrm{M}$
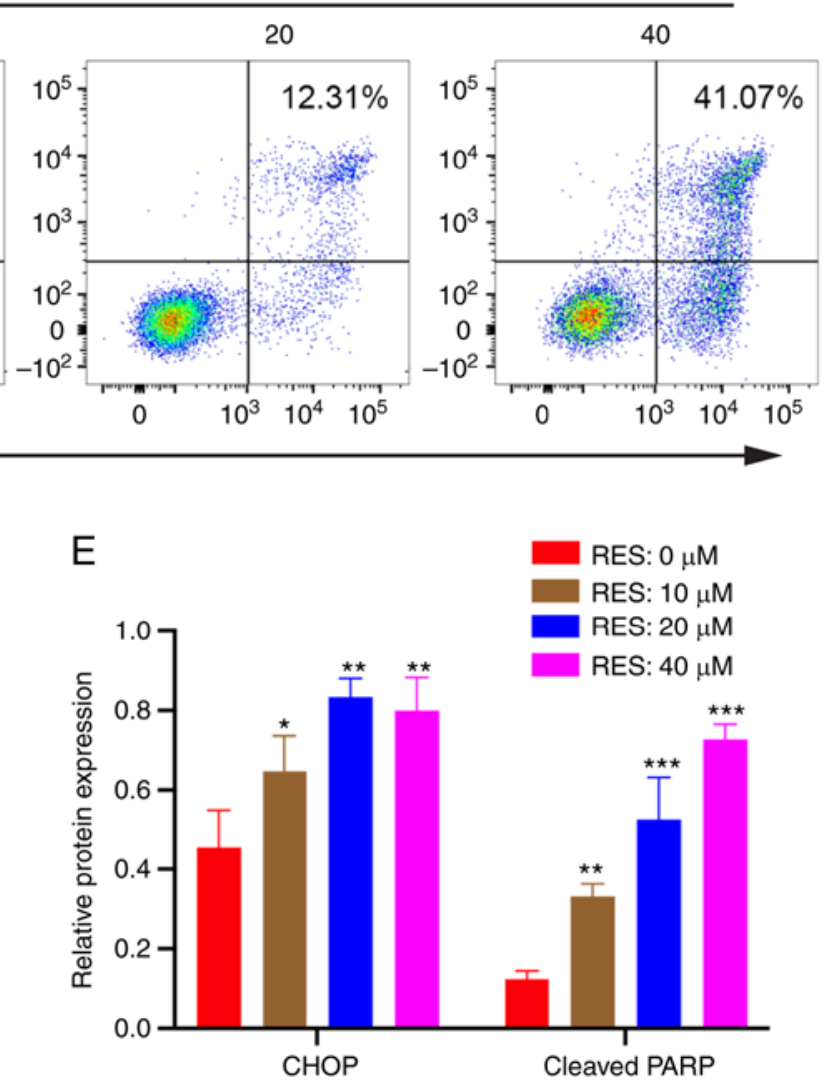

Figure 1. RES inhibits viability and promotes apoptosis of AGS cells. (A) Cell viability was detected by CCK-8 assay after RES treatment (5-80 $\mu \mathrm{M})$ for 24,48 and $72 \mathrm{~h}$. (B) Following exposure to RES (10,20 and $40 \mu \mathrm{M})$ for $48 \mathrm{~h}$, FITC-Annexin V/PI assays and flow cytometry were performed to detect cell apoptosis. (C) The percentage of apoptotic cells (Annexin V-FITC ${ }^{+} / \mathrm{PI}^{+}$quadrant and Annexin V-FITC ${ }^{+} / \mathrm{PI}^{-}$quadrant) was determined. (D and E) The protein expression levels of CHOP and PARP were detected by western blotting upon RES administration for $48 \mathrm{~h}$. Data are presented as the mean $\pm \mathrm{SD}(\mathrm{n}=3)$. ${ }^{*} \mathrm{P}<0.05,{ }^{* *} \mathrm{P}<0.01$ and ${ }^{* * * *} \mathrm{P}<0.001$. RES, resveratrol; DDP, cisplatin; CCK-8, Cell Counting Kit-8; PARP, poly-ADP-ribose polymerase; CHOP, CCAAT/enhancer binding protein homologous protein.

Fig. 2D and E). Collectively, the present results demonstrated that RES and DDP synergistically inhibit AGS cell viability.

RES sensitizes AGS cells to DDP by inducing cell apoptosis. FITC-Annexin V/PI double-staining assays were conducted to assess apoptotic cells after cotreatment with RES $(20 \mu \mathrm{M})$ and DDP $(1 \mu \mathrm{g} / \mathrm{ml})$ for 48 and $72 \mathrm{~h}$ (Fig. 3A). The present results demonstrated that RES/DDP combination treatment for $48 \mathrm{~h}$ induced a higher apoptotic rate compared with that of DDP treatment alone $(\mathrm{P}<0.01$; Fig. 3B). In particular, when the cotreatment time was extended to $72 \mathrm{~h}$, the apoptotic rate was increased and was significantly higher than that under either RES or DDP administration alone ( $\mathrm{P}<0.01$; Fig. 3C).
To investigate the molecular mechanisms underlying the proapoptotic effects of the RES/DDP combination treatment, apoptosis-related proteins were analyzed by western blotting. The results revealed that RES/DDP cotreatment upregulated the levels of the proapoptotic protein Bax and the cleaved form of PARP compared with the levels under DDP treatment alone, whereas expression of the antiapoptotic protein $\mathrm{Bcl}-2$ was downregulated under cotreatment relative to DDP-only treatment $(\mathrm{P}<0.05$; Fig. 3D and E). Collectively, the results indicated that RES enhanced the antitumor effect of DDP on cell apoptosis. mediated apoptotic signaling pathways. To better understand 
A

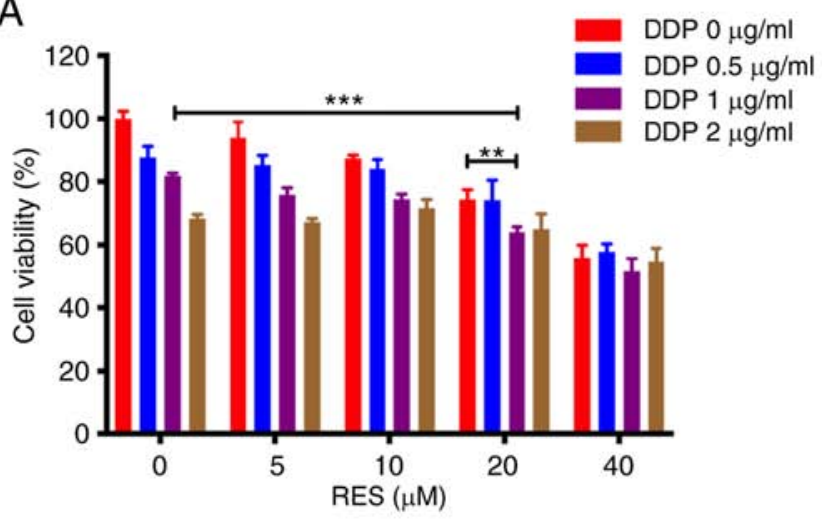

C

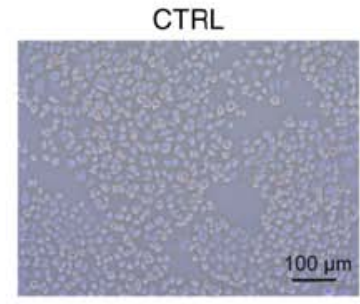

D

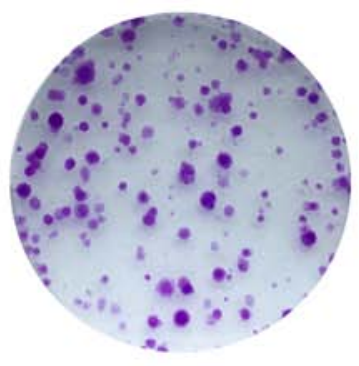

CTRL

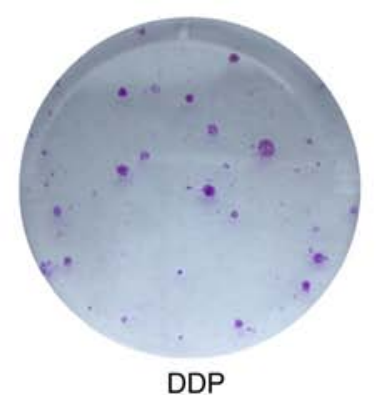

RES
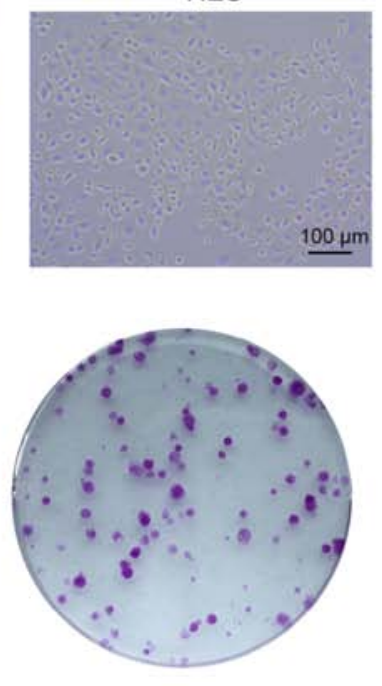

RES

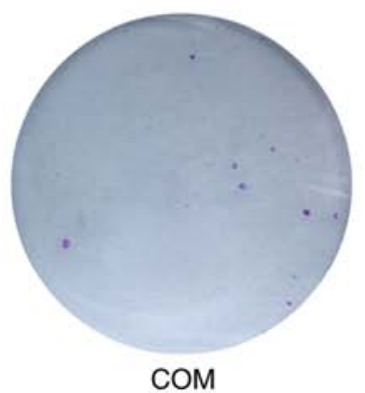

B
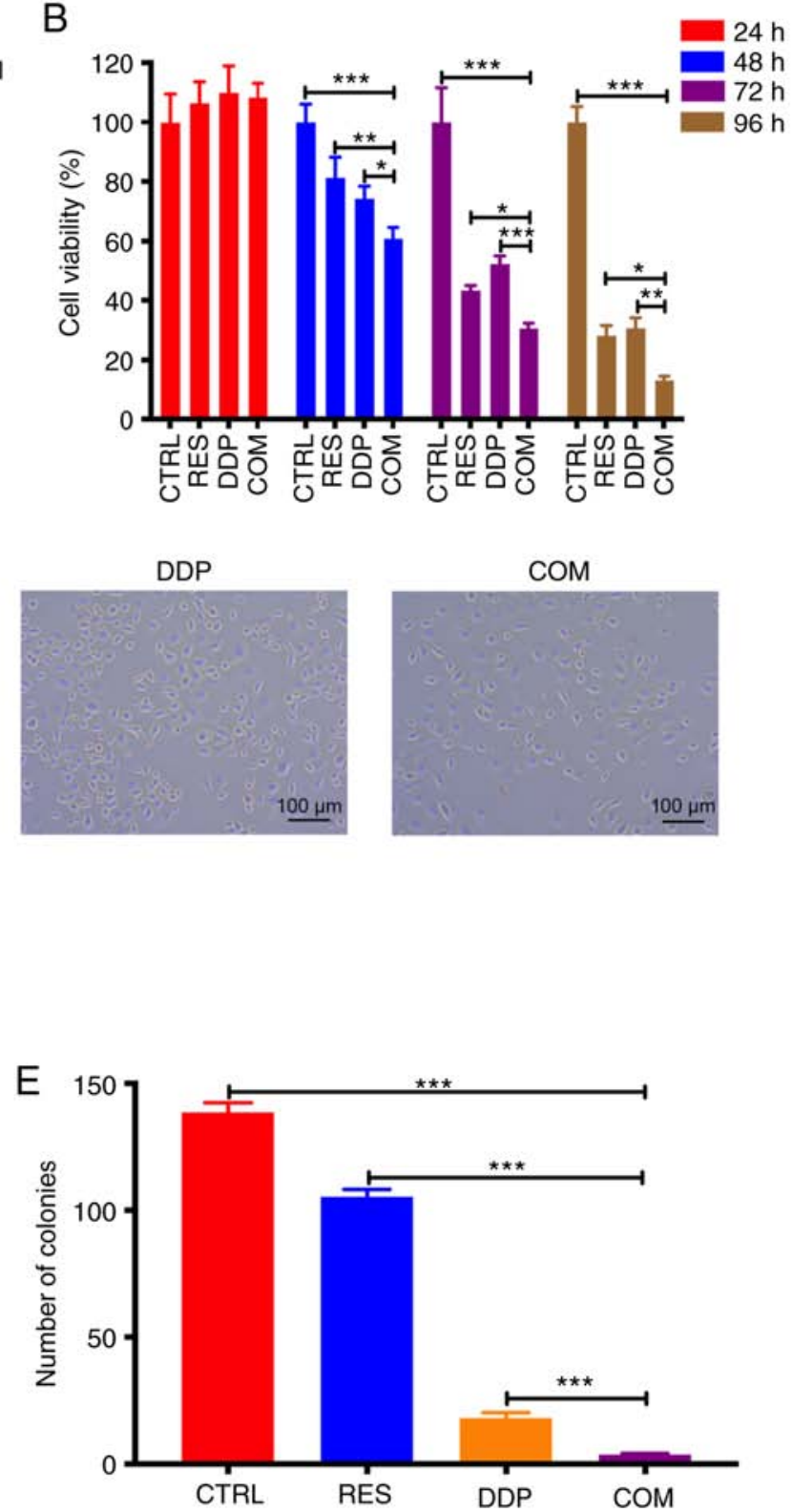

Figure 2. RES and DDP synergistically inhibit AGS cell viability. (A) Cell viability was determined by CCK-8 assay after cotreatment with different doses of RES and DDP for $48 \mathrm{~h}$. (B) Following RES $(20 \mu \mathrm{M})$ and DDP $(1 \mu \mathrm{g} / \mathrm{ml})$ combination treatment for $24,48,72$ and $96 \mathrm{~h}$, cell viability was detected by CCK- 8 assay. (C) The morphological changes in AGS cells were determined after RES $(20 \mu \mathrm{M})$ and DDP $(1 \mu \mathrm{g} / \mathrm{ml})$ cotreatment for $48 \mathrm{~h}$ (magnification, x100). (D) Following RES $(20 \mu \mathrm{M}) / \mathrm{DDP}(1 \mu \mathrm{g} / \mathrm{ml})$ combination treatment for $48 \mathrm{~h}$, colony-forming assays were performed. (E) Colonies in each well were counted. The results are presented as the mean $\pm \mathrm{SD}(\mathrm{n}=3) .{ }^{*} \mathrm{P}<0.05,{ }^{* *} \mathrm{P}<0.01$ and ${ }^{* * *} \mathrm{P}<0.001$. RES, resveratrol; DDP, cisplatin; CCK-8, Cell Counting Kit-8; CTRL, control; COM, combination treatment.

the molecular mechanisms underlying the proapoptotic effects of the RES/DDP combination, western blotting was performed. The expression of the ER stress chaperone GRP78 was significantly upregulated under RES/DDP combination treatment compared to the expression under either single-agent treatment alone ( $\mathrm{P}<0.001$; Fig. $4 \mathrm{~A}$ and $\mathrm{B})$. Moreover, cotreatment with RES and DDP significantly increased PERK, p-eIF2 $\alpha$ and CHOP protein levels but had no significant effect on the expression of eIF $2 \alpha$, indicating that the PERK/eIF2 $\alpha / \mathrm{ATF} 4 / \mathrm{CHOP}$ signaling pathway was activated by cotreatment $(\mathrm{P}<0.05$; Fig. 4A-C). In addition, cleaved caspase-12 was upregulated upon RES and DDP combination treatment compared with its expression under DDP treatment alone $(\mathrm{P}<0.05$; Fig. $4 \mathrm{~A}$ and $\mathrm{B})$. The enhancement of intracellular $\mathrm{Ca}^{2+}$ levels induces ER stress and apoptosis (25). Herein, $\mathrm{Ca}^{2+}$ probes and flow cytometry were applied to evaluate intracellular $\mathrm{Ca}^{2+}$ levels. It was revealed that exposure to RES $(20 \mu \mathrm{M})$ alone for $48 \mathrm{~h}$ caused an increase in $\mathrm{Ca}^{2+}$ levels compared with levels in untreated cells $(\mathrm{P}<0.05$; Fig. 4D and E). However, the RES/DDP 
A

$48 \mathrm{~h}$

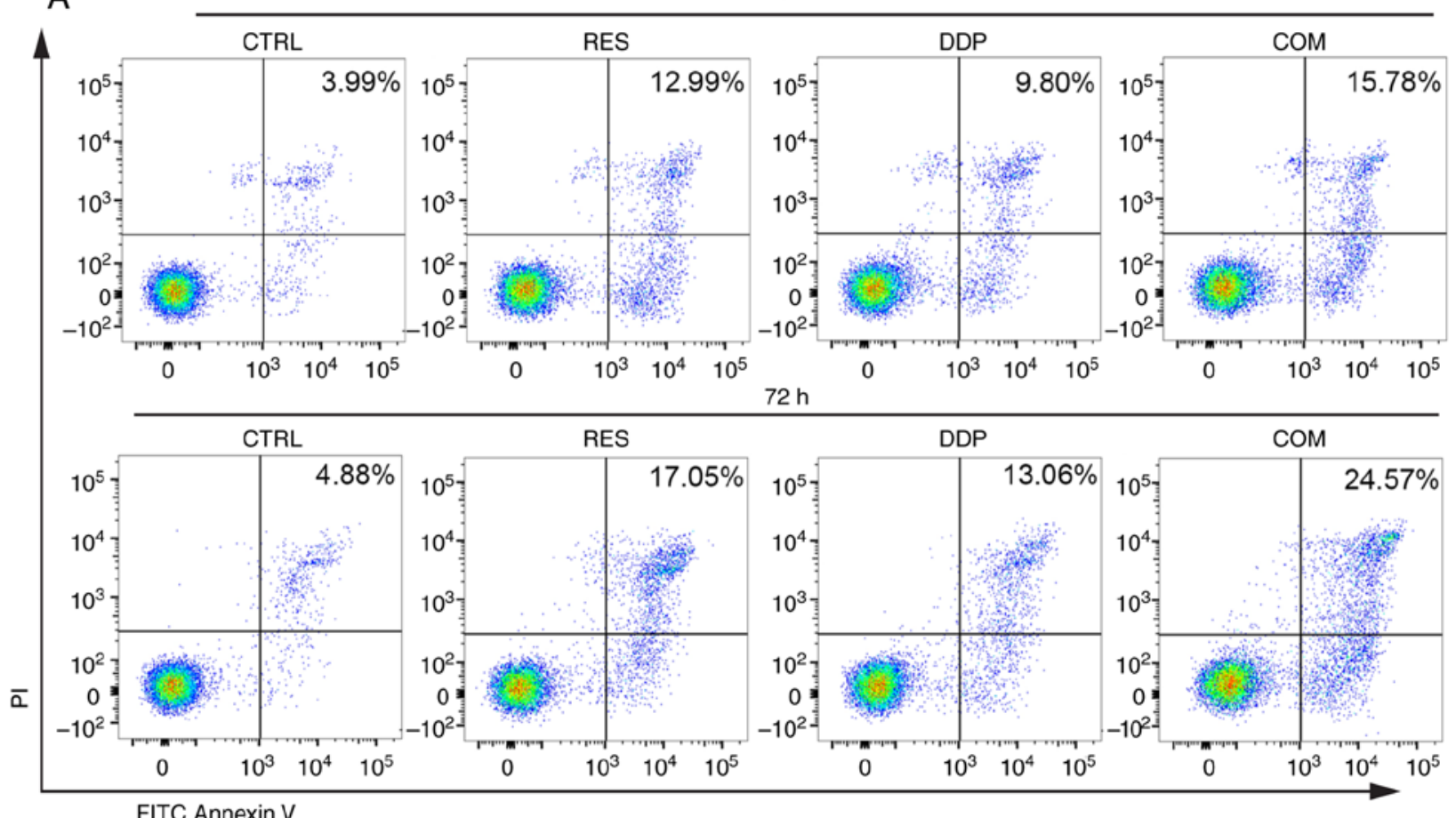

B

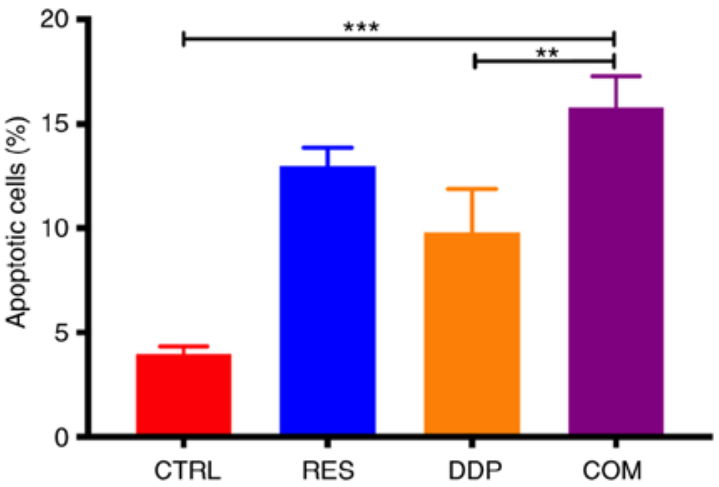

C

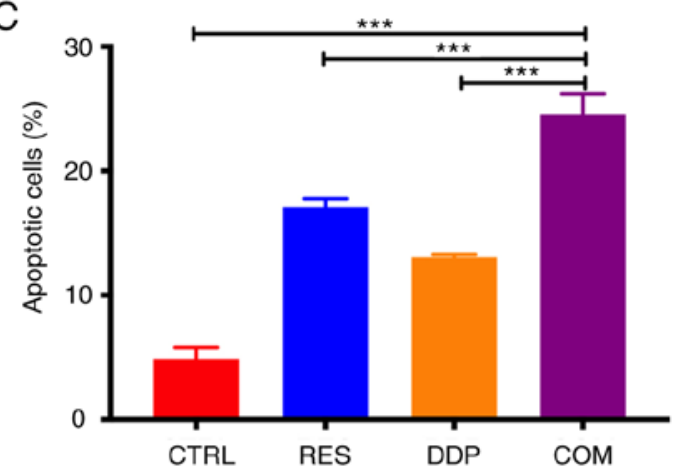

D
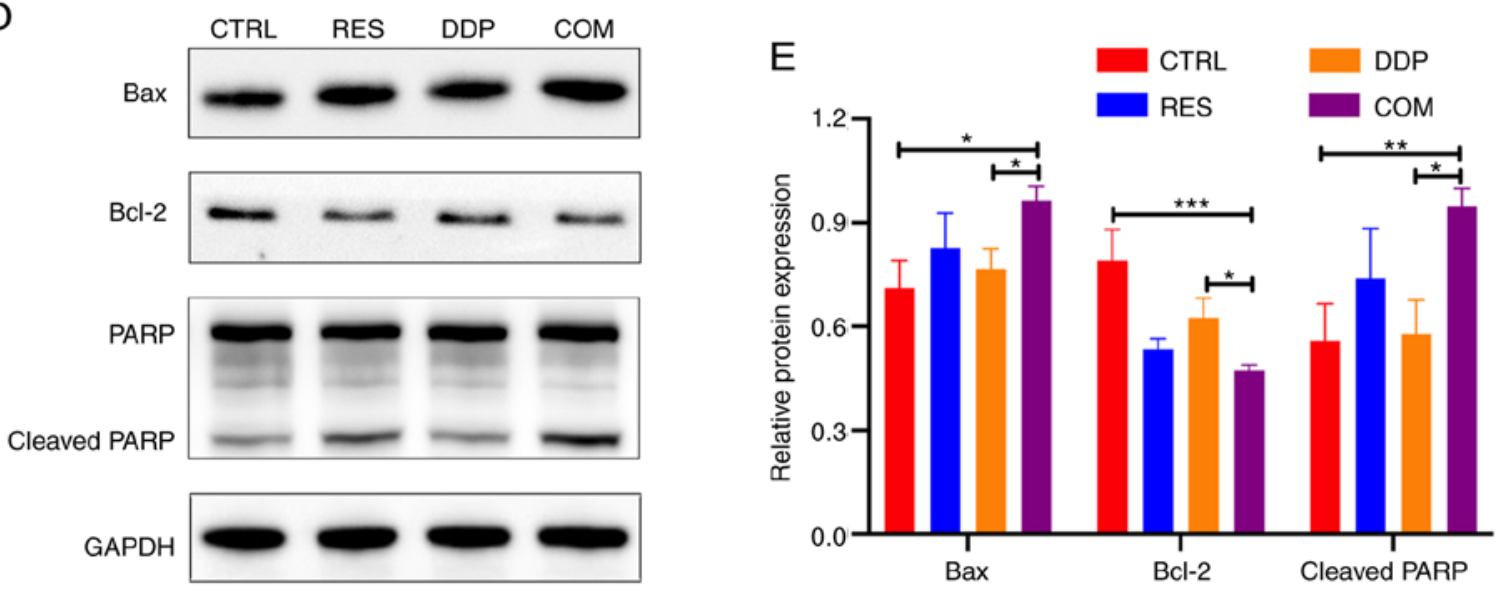

Figure 3. RES sensitizes AGS cells to DDP by inducing cell apoptosis. (A) Cell apoptosis was detected after RES (20 $\mu \mathrm{M})$ and DDP (1 $\mu \mathrm{g} / \mathrm{ml})$ cotreatment for 48 and $72 \mathrm{~h}$ through FITC-Annexin V/PI assays and flow cytometry. (B and C) Histograms revealing the percentage of apoptotic cells. (D and E) The expression levels of Bax, Bcl-2 and PARP were detected by western blotting. The results are presented as the mean $\pm \mathrm{SD}(\mathrm{n}=3)$. ${ }^{*} \mathrm{P}<0.05,{ }^{* *} \mathrm{P}<0.01$ and ${ }^{* * * *} \mathrm{P}<0.001 . \mathrm{RES}$, resveratrol; DDP, cisplatin; PARP, poly-ADP-ribose polymerase; CTRL, control; COM, combination treatment.

combination treatment significantly enhanced the cytosolic $\mathrm{Ca}^{2+}$ levels and exhibited the greatest increase compared with the levels under either single-agent treatment alone $(\mathrm{P}<0.001$;
Fig. 4D and E). These results demonstrated that RES/DDP cotreatment activated ER stress-mediated apoptotic signaling pathways in AGS cells. 
A
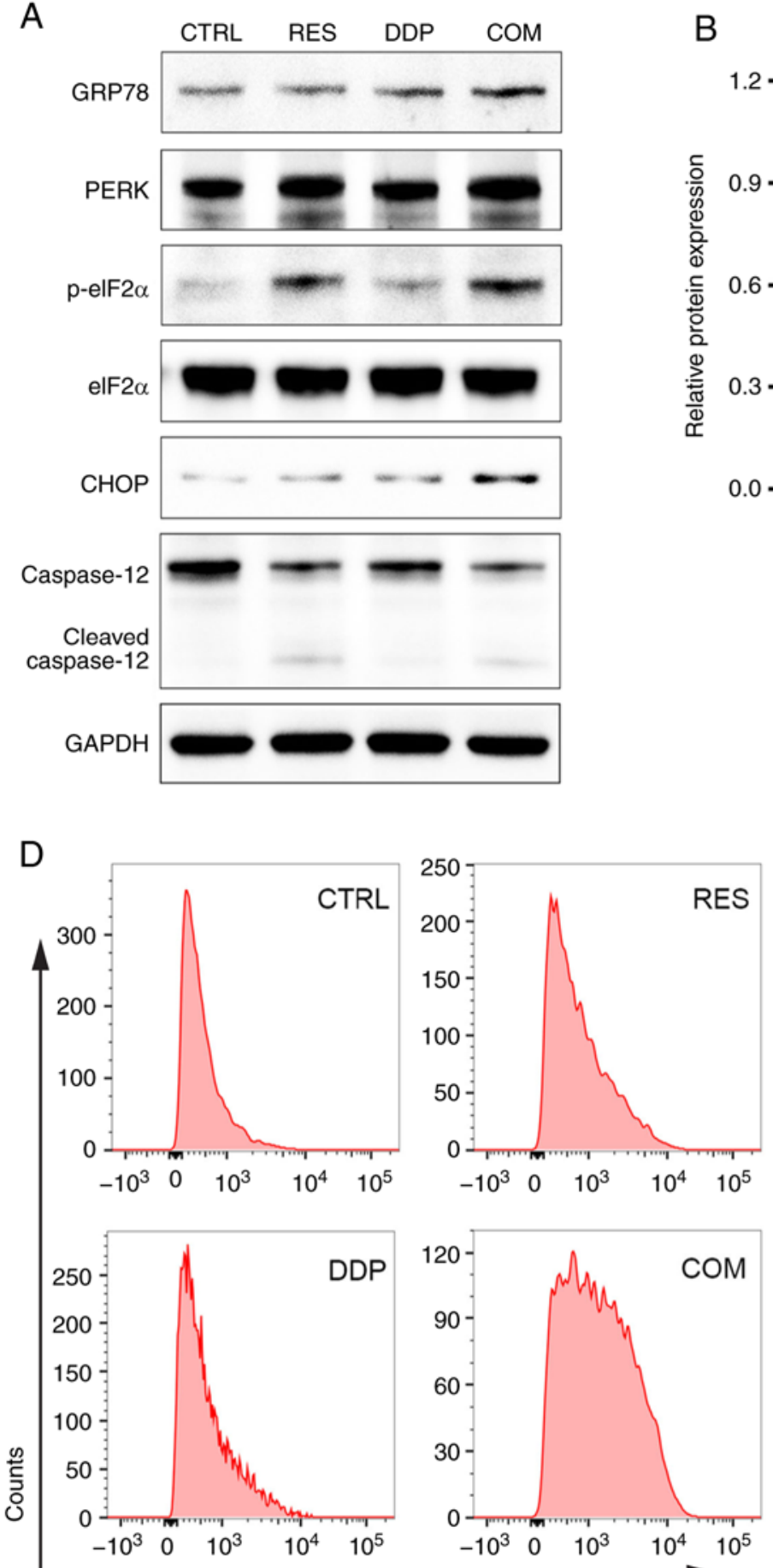

Fluo-4 fluorescence
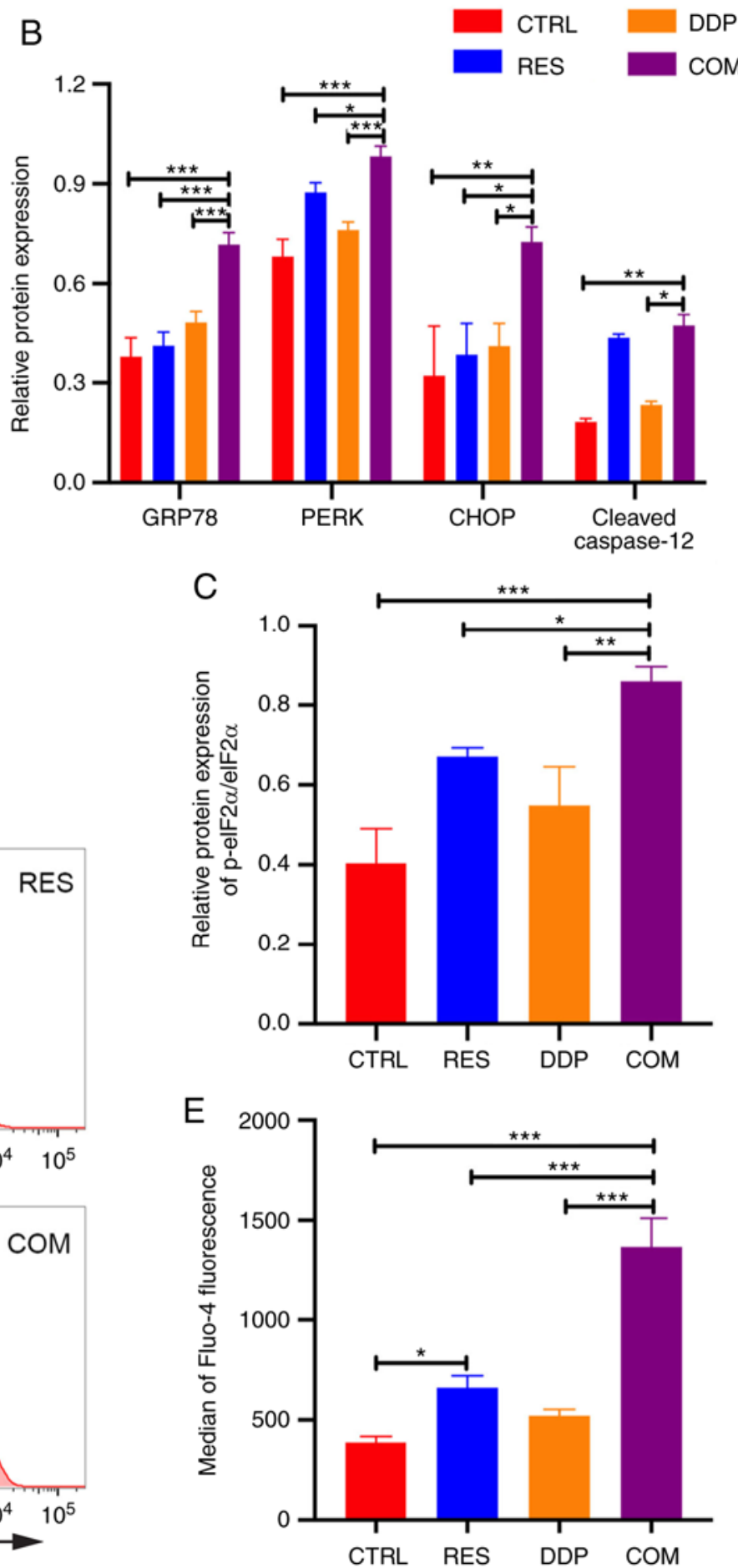

Figure 4. RES/DDP combination treatment activates endoplasmic reticulum stress-mediated apoptotic signaling pathways. (A-C) The protein expression levels of GRP78, PERK, p-eIF2 $\alpha$, eIF2 $\alpha$, CHOP and caspase-12 were determined by western blotting. (D) Fluo-4 AM probe and flow cytometry were used to detect intracellular $\mathrm{Ca}^{2+}$ concentrations after RES $(20 \mu \mathrm{M})$ and DDP $(1 \mu \mathrm{g} / \mathrm{ml})$ cotreatment for $48 \mathrm{~h}$. (E) The median Fluo- 4 fluorescence intensities are presented. The data are presented as the mean $\pm \mathrm{SD}(\mathrm{n}=3) .{ }^{*} \mathrm{P}<0.05,{ }^{* *} \mathrm{P}<0.01$ and ${ }^{* * * *} \mathrm{P}<0.001$. RES, resveratrol; DDP, cisplatin; GRP78, glucose-regulated protein 78 ; PERK, PRKR-like ER kinase; p-eIF2 $\alpha$, phosphorylated eukaryotic translation initiation factor $2 \alpha$; CHOP, CCAAT/enhancer binding protein homologous protein; CTRL, control; COM, combination treatment.

RES sensitizes AGS cells to DDP by inducing G2/M phase arrest. To identify the effect of RES/DDP combination treatment on cell cycle progression, PI staining assays and flow cytometry were performed. As revealed in Fig. 5A-C, RES/DDP cotreatment significantly increased the number of cells in the $\mathrm{G} 2 / \mathrm{M}$ phase compared to the number observed under either single-agent treatment alone $(\mathrm{P}<0.001)$. Moreover, the expression levels of cell cycle progression regulators were detected by western blotting. The present results indicated that upon RES/DDP combination treatment, the phosphorylation level of CDK1 (Tyr15) and the protein levels of p21 $1^{\text {Wafl/Cipl }}$ and p2 $7^{\text {Kipl }}$ were significantly increased, whereas $\mathrm{Cdc} 25 \mathrm{C}$ protein levels were downregulated $(\mathrm{P}<0.05$; Fig. 5D-F). In addition, it was determined that DDP administration significantly 

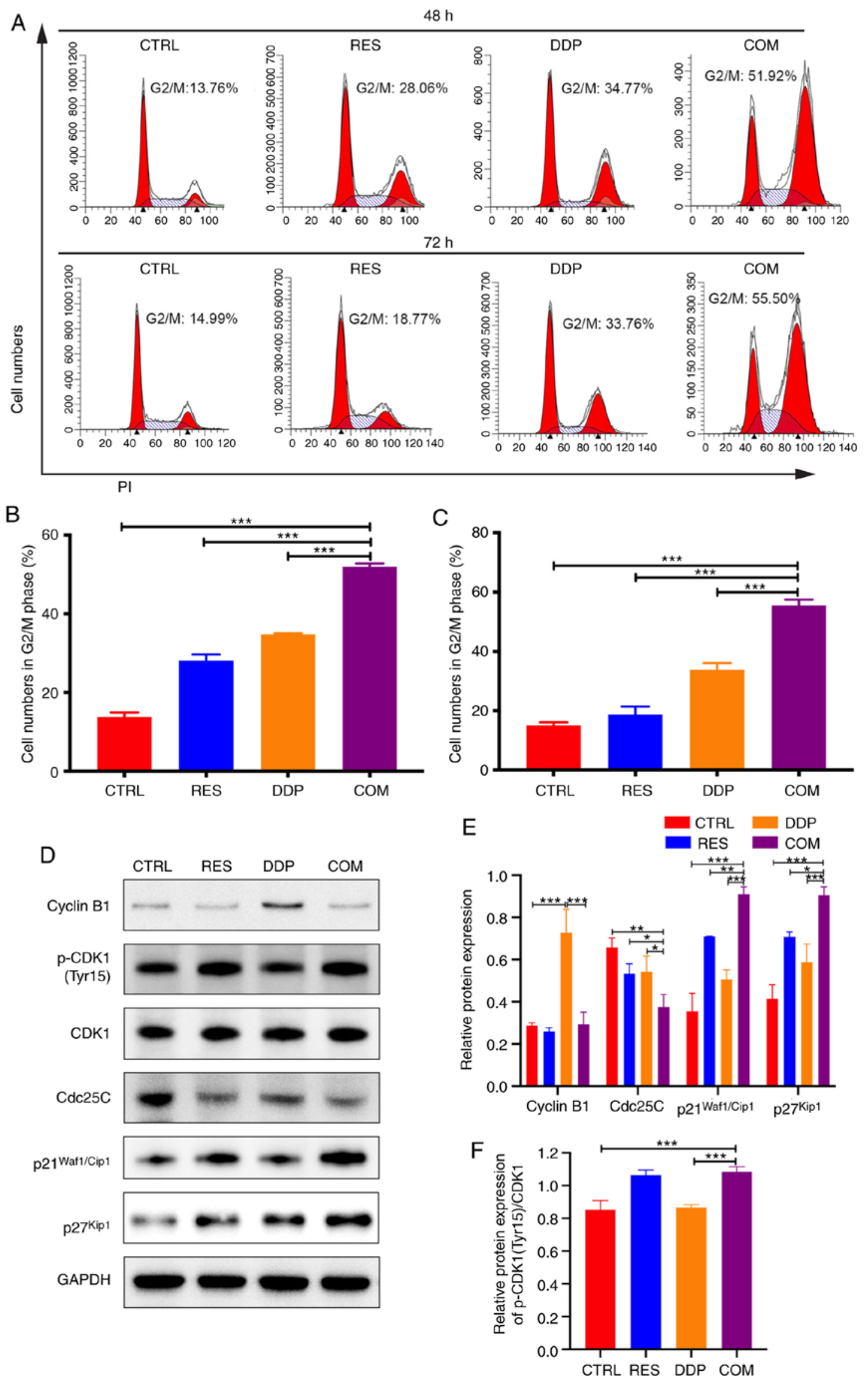

Figure 5. RES sensitizes AGS cells to DDP by inducing G2/M cell cycle arrest. (A) PI staining and flow cytometry were performed to determine cell cycle progression after RES $(20 \mu \mathrm{M})$ and DDP $(1 \mu \mathrm{g} / \mathrm{ml})$ cotreatment for 48 and $72 \mathrm{~h}$. (B and C) The percentage of cells in the G2/M phase was examined. (D-F) After RES $(20 \mu \mathrm{M})$ and DDP $(1 \mu \mathrm{g} / \mathrm{ml})$ combination treatment for $48 \mathrm{~h}$, the protein levels of cyclin B1, p-CDK1 (Tyr15), CDK1, Cdc25C, p21 ${ }^{\text {Wafl/Cipl }}$ and p2 $7^{\mathrm{Kipl}}$ were detected by western blotting. All data are presented as the mean $\pm \mathrm{SD}(\mathrm{n}=3) .{ }^{*} \mathrm{P}<0.05,{ }^{* *} \mathrm{P}<0.01$ and ${ }^{* * *} \mathrm{P}<0.001$. RES, resveratrol; DDP, cisplatin; p-CDK1, phosphorylated cyclin-dependent kinase 1; CTRL, control; COM, combination treatment. 
upregulated cyclin B1 protein expression, while combination treatment of DDP and RES significantly decreased the protein level of cyclin B1 ( $<<0.001$; Fig. 5D and E). These results demonstrated that RES sensitizes AGS cells to DDP by inducing $\mathrm{G} 2 / \mathrm{M}$ phase arrest and by inactivating the CDK1-cyclin B1 complex and upregulating $\mathrm{p} 21^{\text {Waf1/Cip1 }}$ and p2 $7^{\text {Kip1 }}$ expression.

\section{Discussion}

Severe side effects and resistance to chemotherapy have been pressing issues hampering the success of GC treatment (26). Hence, new effective chemotherapeutic strategies are urgently required. RES has been revealed to act as an antineoplastic drug in numerous types of cancers, including GC (12-15,27). However, whether RES and DDP have synergistic effects against GC, and if so, what mechanisms underlie these effects are unknown. In the present study, evidence was provided that RES and DDP synergistically inhibited cell viability, prompted cell apoptosis and induced G2/M cell cycle arrest in gastric adenocarcinoma AGS cells. Furthermore, ER stress-induced apoptosis signaling pathways were significantly activated and the CDK1-cyclin B1 complex was inactivated under RES/DDP combined treatment.

The combination of naturally occurring agents with conventional chemotherapeutic drugs has been applied in the treatment of various types of cancers and can improve therapeutic efficiency and reduce dosages to alleviate toxicity (28). Despite recent advances in molecular targeted therapy and immunotherapy, DDP remains an important component of chemotherapeutic regimens for GC $(5,26)$. However, its systemic toxicity and drug resistance impede its use. RES, a natural polyphenol compound found in plants, is considered to have potent anticancer activity against various types of cancers $(12-15,27)$. Moreover, RES has been reported to act as a chemical sensitizer and to enhance the anticancer effect of DDP in prostate cancer (29), lung cancer $(30,31)$ and hepatoma (32). Herein, it was revealed that RES exerted antineoplastic effects against the GC cell line AGS by suppressing cell viability and promoting cell apoptosis in a dose-dependent manner. Furthermore, the present results demonstrated that RES and DDP synergistically inhibited cell viability and promoted apoptosis of AGS cells, revealing RES as a promising effective chemical sensitizer for DDP treatment in GC patients.

Adverse conditions in the tumor microenvironment, such as nutrient deprivation, oxidative stress, energy perturbations and hypoxia, dysregulate proteostasis of the ER, resulting in a cellular state termed 'ER stress' (33). ER stress triggers the UPR, which subsequently induces prosurvival programs to maintain homeostasis or activates apoptosis when damage is irreversible (34). The UPR is vital for cancer cell survival in adverse environments and induces drug resistance to conventional chemotherapy. Furthermore, blocking the adaptive pathway or promoting the apoptotic pathway of the UPR is a potential antineoplastic strategy since ER stress acts as a 'double-edged sword' during carcinogenesis (18). Previous studies have reported that RES promotes ER stress-mediated apoptosis in colon cancer (19), ovarian cancer (20), and malignant melanoma $(21,35)$. However, the role of RES in regulating the UPR in GC cells is unknown. In the present study, it was revealed that RES/DDP combination treatment significantly upregulated the expression of the ER stress hallmark GRP78 and significantly increased cytoplasmic $\mathrm{Ca}^{2+}$ levels in AGS cells, indicating the occurrence of ER stress under cotreatment.

The PERK/eIF2 $\alpha /$ ATF4/CHOP signaling pathway is an important modulator of ER stress-mediated apoptosis (16). As a UPR signal transducer on the ER membrane, upon activation, PERK phosphorylates eIF2 $\alpha$ at Ser51 to decrease global protein translation but increase ATF4 mRNA expression, thereby upregulating CHOP expression (36). CHOP is an ER stress-associated apoptosis marker that further upregulates the expression of proapoptotic proteins such as death receptor 5 (DR5) and Bim and inhibits the expression of the antiapoptotic protein Bcl-2 (16). Caspase-12 is an ER membrane-resident caspase that is upregulated only upon ER stress, and its activation leads to cleavage of caspase- 9 and caspase-3, resulting in apoptosis (37). Recently, it was reported that RES promotes ER stress-mediated apoptosis in numerous types of cancer cells, such as colon cancer (19), ovarian cancer (20), lung cancer (38), malignant melanoma (21) and nasopharyngeal carcinoma (39). The mechanisms included upregulation of CHOP and activation of PERK and caspase-12. Herein, it was revealed that RES administration upregulated $\mathrm{CHOP}$ expression in a dose-dependent manner. Moreover, RES combined with DDP treatment significantly activated the PERK/eIF2 $\alpha /$ ATF4/CHOP signaling pathway and induced caspase-12 cleavage in AGS gastric adenocarcinoma cells. Therefore, it is suggested that RES/DDP combination treatment promotes ER stress-mediated apoptosis in the GC cell line AGS by activating the PERK/eIF2 $\alpha / \mathrm{ATF} 4 / \mathrm{CHOP}$ signaling pathway and caspase-12.

Dysregulation of cell cycle progression is a hallmark of tumor development, and targeting the cell cycle is an effective antineoplastic strategy (40). Unlike previous studies that revealed that RES blocked GC cells at the G0/G1 phase (41), the present results revealed that RES/DDP combination treatment significantly induced G2/M cell cycle arrest. Moreover, Suttie et al (42) demonstrated that a low dose $(0.156 \mu \mathrm{g} / \mathrm{ml}$, $\mathrm{LD}_{10}$ ) of DDP arrested AGS cells in G0/G1 phase, whereas a high dose $\left(5 \mu \mathrm{g} / \mathrm{ml}, \mathrm{LD}_{50}\right)$ of DDP induced $\mathrm{G} 2 / \mathrm{M}$ phase arrest. In the present study, it was similarly revealed that exposure to low dose of DDP $(0.5 \mu \mathrm{g} / \mathrm{ml})$ for $72 \mathrm{~h}$ induced G0/G1 phase arrest in AGS cells (data not shown). However, DDP treatment $(1 \mu \mathrm{g} / \mathrm{ml})$ for 48 or $72 \mathrm{~h}$ led to $\mathrm{G} 2 / \mathrm{M}$ cell cycle arrest. Based on the previous literature and our experimental results, we speculate that differences in cell cycle phase arrest in AGS cells are associated with differences in the dose of DDP. In addition, the proteins regulating cell cycle progression at the $\mathrm{G} 2 / \mathrm{M}$ checkpoint were detected by western blotting. The CDK1-cyclin B1 complex plays a critical role in the G2/M transition (43). The downregulation or inactivation of either CDK1 (also known as $\mathrm{Cdc} 2$ ) or cyclin $\mathrm{B} 1$ blocks cell cycle progression to the $\mathrm{G} 2$ phase. Furthermore, the activity of CDK1 is regulated by Cdc $25 \mathrm{C}$, a phosphatase, which dephosphorylates CDK1 at Thr14 and Tyr15 residues, leading to the activation of the CDK1-cyclin B1 complex (44). p2 $1^{\text {Waf1/Cip1 }}$ and $\mathrm{p} 27^{\mathrm{Kip} 1}$ are cyclin-dependent kinase inhibitors (CKIs) that reduce the activity of CDK1 (45), and both are thought to be tumor suppressive. In the present 
study, it was determined that RES/DDP combination treatment upregulated the protein levels of p-CDK1 (Tyr15), p21 $1^{\text {Waf1/Cip1 }}$ and $\mathrm{p} 27^{\mathrm{Kip}}$, downregulated $\mathrm{Cdc} 25 \mathrm{C}$ expression, and reduced cyclin $\mathrm{B} 1$ protein expression (which was increased by DDP administration alone), leading to $\mathrm{G} 2 / \mathrm{M}$ phase arrest.

There are certain limitations to the present study worth mentioning. The primary limitation is that the target protein and molecular mechanisms are currently not fully defined and further research is required. In this study, we only presented the possible molecular mechanisms underlying the antineoplastic effects for RES/DDP cotreatment by activating ER stress-mediated apoptosis and suppressing the activity of CDK1-cyclin B1 complex. Further exploration of the specific mechanisms would be addressed in a future study. In addition, we may also perform rescue experiments to validate the specificity of the signaling pathways. Since increase of $\mathrm{Ca}^{2+}$ during ER stress has been revealed to be mainly associated with inositol trisphosphate receptors (IP3R) (46), future experiments such as blocking or downregulating IP3R are required to clarify the relationship between RES/DDP combination treatment and $\mathrm{Ca}^{2+}$ levels.

In conclusion, it was revealed that RES and DDP synergistically inhibited cell growth of the GC cell line AGS by inducing ER stress-mediated apoptosis and G2/M phase arrest. Further experiments revealed that the PERK/eIF2 $\alpha / \mathrm{ATF} 4 / \mathrm{CHOP}$ signaling pathway and caspase-12 were activated by RES/DDP cotreatment. Additionally, RES/DDP combination treatment suppressed the activity of the CDK1-cyclin B1 complex and upregulated $\mathrm{p} 21^{\text {Waf1/Cip1 }}$ and $\mathrm{p} 27^{\mathrm{Kip} 1}$ expression to arrest AGS cells in G2/M phase. These findings identify RES as a promising adjuvant for GC chemotherapy.

\section{Acknowledgements}

The authors would like to thank the State Key Laboratory for Diagnosis and Treatment of Infectious Diseases of the First Affiliated Hospital of Zhejiang University for excellent technical assistance.

\section{Funding}

The present study was supported by Zhejiang Traditional Chinese Medicine Science and Technology Project (grant no. 2017ZZ010), the Key Research and Development Program of Zhejiang Province (grant no. 2019C03031), and the Zhejiang Medical Science and Technology Program (grant no. 2018266817).

\section{Availability of data and materials}

The datasets used and/or analyzed during the current study are available from the corresponding author on reasonable request.

\section{Authors' contributions}

MR and $\mathrm{XZ}$ contributed equally to this study. MR, $\mathrm{XZ}$ and MG designed and performed the experiments. WJ and JY performed part of the experiments. MY, YW and SL contributed to the data analysis. MR wrote the manuscript. $\mathrm{XZ}$ and MG reviewed and edited the manuscript. FJ conceived the study and was responsible for the revision of the manuscript and final decision to submit the article for publication. All authors read and approved the final manuscript.

\section{Ethics approval and consent to participate}

Not applicable.

\section{Patient consent for publication}

Not applicable.

\section{Competing interests}

The authors declare that they have no competing interests.

\section{References}

1. Siegel RL, Miller KD and Jemal A: Cancer statistics, 2019. Ca Cancer J Clin 69: 7-34, 2019.

2. Bray F, Ferlay J, Soerjomataram I, Siegel RL, Torre LA and Jemal A: Global cancer statistics 2018: GLOBOCAN estimates of incidence and mortality worldwide for 36 cancers in 185 countries. Ca Cancer J Clin 68: 394-424, 2018.

3. Van Cutsem E, Sagaert X, Topal B, Haustermans K and Prenen H: Gastric cancer. Lancet 388: 2654-2664, 2016.

4. Wang FH, Shen L, Li J, Zhou ZW, Liang H, Zhang XT, Tang L, Xin Y, Jin J, Zhang YJ, et al: The Chinese society of clinical oncology (CSCO): Clinical guidelines for the diagnosis and treatment of gastric cancer. Cancer Commun (Lond) 39: 10, 2019.

5. Yamada Y, Higuchi K, Nishikawa K, Gotoh M, Fuse N, Sugimoto N, Nishina T, Amagai K, Chin K, Niwa Y, et al: Phase III study comparing oxaliplatin plus S-1 with cisplatin plus $\mathrm{S}-1$ in chemotherapy-naive patients with advanced gastric cancer. Ann Oncol 26: 141-148, 2015.

6. Quintanilha JCF, Saavedra KF, Visacri MB, Moriel P and Salazar LA: Role of epigenetic mechanisms in cisplatin-induced toxicity. Crit Rev Oncol Hematol 137: 131-142, 2019.

7. Berman AY, Motechin RA, Wiesenfeld MY and Holz MK: The therapeutic potential of resveratrol: A review of clinical trials. NPJ Precis Oncol 1: 35, 2017.

8. Bonnefont-Rousselot D: Resveratrol and cardiovascular diseases. Nutrients 8: 250, 2016.

9. Ahmed T, Javed S, Javed S, Tariq A, Šamec D, Tejada S, Nabavi SF, Braidy N and Nabavi SM: Resveratrol and Alzheimer's disease: Mechanistic insights. Mol Neurobiol 54: 2622-2635, 2017.

10. Nunes S, Danesi F, Del Rio D and Silva P: Resveratrol and inflammatory bowel disease: The evidence so far. Nutr Res Rev 31: 85-97, 2018.

11. Wong RHX and Howe PRC: Resveratrol counteracts insulin resistance-potential role of the circulation. Nutrients 10: 1160, 2018.

12. Jiang Z, Chen K, Cheng L, Yan B, Qian W, Cao J, Li J, Wu E, Ma Q and Yang W: Resveratrol and cancer treatment: Updates. Ann N Y Acad Sci 1403: 59-69, 2017.

13. Zulueta A, Caretti A, Signorelli P and Ghidoni R: Resveratrol: A potential challenger against gastric cancer. World J Gastroenterol 21: 10636-10643, 2015.

14. Zhou HB, Chen JJ, Wang WX, Cai JT and Du Q: Anticancer activity of resveratrol on implanted human primary gastric carcinoma cells in nude mice. World J Gastroenterol 11: 280-284, 2005.

15. Yang Z, Xie Q, Chen Z, Ni H, Xia L, Zhao Q, Chen Z and Chen P: Resveratrol suppresses the invasion and migration of human gastric cancer cells via inhibition of MALAT1-mediated epithelial-to-mesenchymal transition. Exp Ther Med 17: 1569-1578, 2019

16. Wang $M$ and Kaufman RJ: Protein misfolding in the endoplasmic reticulum as a conduit to human disease. Nature 529: 326-335, 2016.

17. Hetz $C$ and Papa FR: The unfolded protein response and cell fate control. Mol Cell 69: 169-181, 2018.

18. Kim C and Kim B: Anti-cancer natural products and their bioactive compounds inducing ER stress-mediated apoptosis: A review. Nutrients 10: 1021, 2018.

19. Park JW, Woo KJ, Lee JT, Lim JH, Lee TJ, Kim SH, Choi YH and Kwon TK: Resveratrol induces pro-apoptotic endoplasmic reticulum stress in human colon cancer cells. Oncol Rep 18: 1269-1273, 2007. 
20. Gwak H, Kim S, Dhanasekaran DN and Song YS: Resveratrol triggers ER stress-mediated apoptosis by disrupting N-linked glycosylation of proteins in ovarian cancer cells. Cancer Lett 371: 347-353, 2016.

21. Heo JR, Kim SM, Hwang KA, Kang JH and Choi KC: Resveratrol induced reactive oxygen species and endoplasmic reticulum stressmediated apoptosis, and cell cycle arrest in the A375SM malignant melanoma cell line. Int J Mol Med 42: 1427-1435, 2018.

22. Chou TC: Drug combination studies and their synergy quantification using the Chou-Talalay method. Cancer Res 70: 440-446, 2010.

23. Gu ML, Wang YM, Zhou XX, Yao HP, Zheng S, Xiang Z and Ji F: An inhibitor of the acetyltransferases CBP/p300 exerts antineoplastic effects on gastrointestinal stromal tumor cells. Oncol Rep 36: 2763-2770, 2016.

24. Wang YM, Gu ML, Meng FS, Jiao WR, Zhou XX, Yao HP and Ji F: Histone acetyltransferase p300/CBP inhibitor C646 blocks the survival and invasion pathways of gastric cancer cell lines. Int J Oncol 51: 1860-1868, 2017.

25. Bahar E, Kim H and Yoon H: ER stress-mediated signaling: Action potential and ca(2+) as key players. Int J Mol Sci 17: 1558, 2016

26. Wagner AD, Syn NL, Moehler M, Grothe W, Yong WP, Tai BC Ho J and Unverzagt S: Chemotherapy for advanced gastric cancer. Cochrane Database Syst Rev 8: CD004064, 2017.

27. Athar M, Back JH, Kopelovich L, Bickers DR and Kim AL: Multiple molecular targets of resveratrol: Anti-carcinogenic mechanisms. Arch Biochem Biophys 486: 95-102, 2009.

28. Lin SR, Chang CH, Hsu CF, Tsai MJ, Cheng H, Leong MK, Sung PJ, Chen JC and Weng CF: Natural compounds as potential adjuvants to cancer therapy: Preclinical evidence. Br J Pharmacol 177: 1409-1423, 2020.

29. Martínez-Martínez D, Soto A, Gil-Araujo B, Gallego B, Chiloeches A and Lasa M: Resveratrol promotes apoptosis through the induction of dual specificity phosphatase 1 and sensitizes prostate cancer cells to cisplatin. Food Chem Toxicol 124: 273-279, 2019

30. Li W, Shi Y, Wang R, Pan L, Ma L and Jin F: Resveratrol promotes the sensitivity of small-cell lung cancer $\mathrm{H} 446$ cells to cisplatin by regulating intrinsic apoptosis. Int J Oncol 53: 2123-2130, 2018.

31. Ma L, Li W, Wang R, Nan Y, Wang Q, Liu W and Jin F: Resveratrol enhanced anticancer effects of cisplatin on non-small cell lung cancer cell lines by inducing mitochondrial dysfunction and cell apoptosis. Int J Oncol 47: 1460-1468, 2015.

32. Liu Z, Peng Q, Li Y and Gao Y: Resveratrol enhances cisplatin-induced apoptosis in human hepatoma cells via glutamine metabolism inhibition. BMB Rep 51: 474-479, 2018.

33. Cubillos-Ruiz JR, Bettigole SE and Glimcher LH: Tumorigenic and immunosuppressive effects of endoplasmic reticulum stress in cancer. Cell 168: 692-706, 2017.
34. Corazzari M, Gagliardi M, Fimia GM and Piacentini M: Endoplasmic reticulum stress, unfolded protein response, and cancer cell fate. Front Oncol 7: 78, 2017.

35. Limonta P, Moretti RM, Marzagalli M, Fontana F, Raimondi M and Montagnani Marelli M: Role of endoplasmic reticulum stress in the anticancer activity of natural compounds. Int $\mathrm{J}$ Mol Sci 20: 961, 2019.

36. Urra H, Dufey E, Avril T, Chevet E and Hetz C: Endoplasmic reticulum stress and the hallmarks of cancer. Trends Cancer 2: 252-262, 2016.

37. Rao RV, Ellerby HM and Bredesen DE: Coupling endoplasmic reticulum stress to the cell death program. Cell Death Differ 11: 372-380, 2004

38. Gu S, Chen C, Jiang X and Zhang Z: ROS-mediated endoplasmic reticulum stress and mitochondrial dysfunction underlie apoptosis induced by resveratrol and arsenic trioxide in A549 cells. Chem Biol Interact 245: 100-109, 2016.

39. Chow SE, Kao CH, Liu YT, Cheng ML, Yang YW, Huang YK, Hsu CC and Wang JS: Resveratrol induced ER expansion and ER caspase-mediated apoptosis in human nasopharyngeal carcinoma cells. Apoptosis 19: 527-541, 2014.

40. Otto T and Sicinski P: Cell cycle proteins as promising targets in cancer therapy. Nat Rev Cancer 17: 93-115, 2017.

41. Shin KO, Park NY, Seo CH, Hong SP, Oh KW, Hong JT, Han SK and Lee YM: Inhibition of sphingolipid metabolism enhances resveratrol chemotherapy in human gastric cancer cells. Biomol Ther (Seoul) 20: 470-476, 2012.

42. SuttieSA,ParkKGandSmithTA:[18F]2-fluoro-2-deoxy-D-glucose incorporation by AGS gastric adenocarcinoma cells in vitro during response to epirubicin, cisplatin and 5-fluorouracil. Br J Cancer 97: 902-909, 2007.

43. Satyanarayana A and Kaldis P: Mammalian cell-cycle regulation: Several Cdks, numerous cyclins and diverse compensatory mechanisms. Oncogene 28: 2925-2939, 2009.

44. Perdiguero E and Nebreda AR: Regulation of Cdc25C activity during the meiotic G2/M transition. Cell Cycle 3: 733-737, 2004.

45. Hu X and Moscinski LC: Cdc2: A monopotent or pluripotent CDK? Cell Prolif 44: 205-211, 2011.

46. Berridge MJ: Inositol trisphosphate and calcium signalling. Nature 361: 315-325, 1993.

This work is licensed under a Creative Commons Attribution-NonCommercial-NoDerivatives 4.0 International (CC BY-NC-ND 4.0) License. 